The Philosophical Journal of Conflict and Violence

Vol. III, Issue 2/2019

(C) The Authors 2019

Available online at http://trivent-publishing.eu/

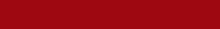

\title{
Joseph de Maistre on War and Peace: Ritual and Realism
}

\author{
Daniel Rosenberg \\ Hebrew University of Jerusalem, Israel \\ daniel.rosenberg@mail.huji.ac.il
}

\begin{abstract}
The essay analyses the development of Joseph de Maistre's ideas on war and peace. Commonly seen as advocating militarism and bloodshed, Maistre's insights and propositions on the nature of war are in fact highly modern and original. As a witness to the European upheaval of 1792-1815, Maistre emphasizes the indeterminacy and unpredictability of modern war, and its irreducibility to a science or a doctrine. In order to regulate and restrain warfare, Maistre argues, it is necessary to cultivate public opinion, an elusive and difficult process which can only be sustained by informal cultural institutions. The essay also examines the legacy of Maistre's ideas on war and peace in political thought.
\end{abstract}

Keywords: Joseph de Maistre; War; Counter-revolution; Napoleonic Wars; Russia; Sacrifice; Realism, Public Opinion.

DOI: $10.22618 /$ TP.PJCV.20204.1.201003

The PJCV Journal is published by Trivent Publishing

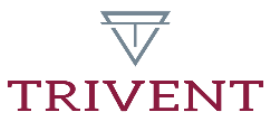

This is an Open Access article distributed in accordance with the Creative Commons Attribution Non Commercial (CCBY-NC-ND 4.0) license, which permits others to copy or share the article, provided original work is properly cited and that this is not done for commercial purposes. Users may not remix, transform, or build upon the material and may not distribute the modified material (bttp:/ / creativecommons.org/ licenses/by-nc/4.0/) 


\title{
Joseph de Maistre on War and Peace: Ritual and Realism
}

\author{
Daniel Rosenberg \\ Hebrew University of Jerusalem, Israel \\ daniel.rosenberg@mail.huji.ac.il
}

\begin{abstract}
The essay analyses the development of Joseph de Maistre's ideas on war and peace. Commonly seen as advocating militarism and bloodshed, Maistre's insights and propositions on the nature of war are in fact highly modern and original. As a witness to the European upheaval of 1792-1815, Maistre emphasizes the indeterminacy and unpredictability of modern war, and its irreducibility to a science or a doctrine. In order to regulate and restrain warfare, Maistre argues, it is necessary to cultivate public opinion, an elusive and difficult process which can only be sustained by informal cultural institutions. The essay also examines the legacy of Maistre's ideas on war and peace in political thought.
\end{abstract}

Keywords: Joseph de Maistre; War; Counter-revolution; Napoleonic Wars; Russia; Sacrifice; Realism, Public Opinion.

\section{Introduction}

War and violence play a major role in Joseph de Maistre's political philosophy. The late $18^{\text {th }}$ early $19^{\text {th }}$ century thinker, known primarily for his relentless attack on the revolutionary regime in France and its underlying democratic philosophy, is famous also for his bloody view of human society. One of Maistre's points about human society is, indeed, its "chronic" and inherent tendency towards irredeemable brutality. Maistre's work displays interest, even fascination with violence and war in particular, which he considers as innate to all human societies, including in those founded on the virtuous values of the Enlightenment; in his words: "there is nothing but violence in the world; but we are tainted by modern philosophy which has taught us that all is good." 1 Violence and conflict do not arise from any faulty social or political structure but are embedded in the very behaviour of the human animal.

In the post-war era, the common view of Maistre's thought on the topic was largely framed by Isaiah Berlin, who, in his canonization of "Counter-Enlightenment" thought, offered a view of Maistre's ideas as hopelessly pessimistic and repressive. According to Berlin,

in place of science [Maistre] preached the primacy of instinct, Christian wisdom, prejudice (which is but the fruit of the experience of generations), blind faith; in place of optimism , pessimism ; in place of eternal harmony and eternal peace, the necessity — the divine necessity — of conflict and

\footnotetext{
${ }^{1}$ Joseph de Maistre, "Considerations on France," in The Generative Principle of Political Constitutions: Studies on Sovereignty, Religion and Enlightenment, ed. and trans. Jack Lively (New Brunswick and London: Transaction Publishers, 2013), 64.
} 
suffering, sin and retribution, bloodshed and war. In place of the ideals of peace and social equality, founded on the common interests and the natural goodness of man, he asserted the inherent inequality and violent conflict of aims and interests as being the normal condition of fallen man and the nations to which he belonged. ${ }^{2}$

Following Berlin's essay, it has become nearly commonplace to consider Maistre as one of the founders of the western anti-Enlightenment or anti-liberal tradition, a view which has been stated in numerous pieces of commentary. ${ }^{3}$

Since the publication of Berlin's essay, scholarship on Joseph de Maistre has begun to adopt another view of the thinker. Some scholars have focused on the modernity of Maistre's works, demonstrating the intricate ways in which Maistre anticipated, criticized, and even inspired some of the developments in $19^{\text {th }}$ and $20^{\text {th }}$ century social and political thought. ${ }^{4}$ Relevant to the discussion on the subject of war and peace is Cara Camcastle's 2005 publication More Moderate Side of Joseph de Maistre: Views on Political Liberty and Political Economy. This monograph comprises a thorough analysis of Maistre's letters, brochures, and other ad hoc writings, and exposed Maistre's political perspective as highly nuanced; Maistre's pessimism, according to this view, does not lead to blind vindication of violence, but to a distinctly prudent view on political matters. ${ }^{5}$

This view, which joins other "revisionist" analyses of Maistre's ideas on war and peace, frames Maistre's ideas as rooted staunchly in the tradition of classical realism, of Hobbes and Grotius. ${ }^{6}$ While these interpretations fill a large gap and correct some misconceptions concerning Maistre's thought, they tend to overstate the a priori unity of Maistre's intellectual corpus. The current essay takes a different approach, by analysing the evolution of the Maistrean perspective on the subject by relating it to the political and historical-intellectual developments of his day. Rather than addressing Maistre's ideas en bloc, the essay highlights the immediately circumstantial aspects in his reflections. By doing so, the essay aims to reframe the "realism" of Maistre's ideas on war and peace in showing the historicallycontingent style of his reasoning; rather than an account of human nature as such, Maistre offers a critique of a particularly modern type of warfare and of its political and social traits.

Pursuing this perspective, the essay analyses Maistre's ideas concerning the regulation of warfare; ideas which draw upon Maistre's experience from the revolutionary and Napoleonic wars. In order to moderate the more destructive forms of warfare and escalation, Mais tre endorses traditional institutions which are rooted in culture and public opinion and enjoy relative independence from established political powers. By prioritizing the role of public opinion and informal institutions in the maintenance of peace, Maistre's approach appears as less harshly "realistic" and more as a mitigated form of "constructivism." The essay concludes with an overview of the legacy of Maistre's ideas on war and peace in the $19^{\text {th }}$ and $20^{\text {th }}$ centuries; the highly divergent reception of Maistre's legacy demonstrates the multifaceted

\footnotetext{
${ }^{2}$ Isaiah Berlin, The Crooked Timber of Humanity: Chapters in the History of Ideas (London: John Murray, 1990), 108-109.

${ }^{3}$ See Stephan Holmes, The Anatomy of Antiliberalism (Cambridge, Mass.: Harvard University Press, 1993). ${ }^{4}$ Owen Bradley, A Modern Maistre: the Social and Political Thought of Joseph de Maistre (Lincoln, Neb. and London: University of Nebraska Press, 1999); Carolina Armenteros, The French Idea of History: and His Heirs, 1794-1854 (Ithaca, N.Y.: Cornell University Press, 2011).

${ }^{5}$ Cara Camcastle, More Moderate Side of Joseph de Maistre: Views on Political Liberty and Political Economy (Montreal: McGill-Queen's University Press, 2005); see especially chapter IV: "The Balance of Power." ${ }^{6}$ Richard Lebrun, "Joseph de Maistre's "Philosophic" View of War," Proceedings of the Annual Meeting of the Western Society for French History 7 (1979): 43-52. Lebrun frames Maistre's ideas on the subject as an expression of Catholic moralism.
} 
and contingent character of his ideas on the subject, further showcasing the paradoxical and ambiguous modernity of his thought.

\section{Maistre's Views of War and Peace before 1800: from National to Universal War}

The development of Maistre's early ideas on warfare, like many other aspects of his thought, is tinged by a strong sense of paradox. Maistre begins his considerations from a highly specific and even provincial perspective, as a Savoyard nobleman concerned primarily with the safety of his minor Alpine state. It would only be after the dénouement of the French Revolution that Maistre would adopt a broader and more critical perspective on the nature of war and peace, primarily as a response and a critique to Enlightenment philosophy. The change of perspective which occurred in Maistre's thought during the mid-1790s is important in order to understand his more mature ideas on the subject of war and peace.

Maistre's earliest comments on military topics can be traced to his writings as a young senator in the Duchy of Savoy. Among his early writings, which are mostly advisory in nature, one is directly related to the issue of war and peace: in his work dating from 1775, a eulogy addressed to the King of Sardinia, Victor Amadeus III. In this letter, Maistre hands the King a list of advices concerning war and peace; in a typically vivid style that would become a staple of his rhetoric, Maistre affirms that "we all go, if necessary, to spill blood at your side; when we fight under your flags, we will be sure to fight for justice, love will show us the road to glory; you will be proud of your subjects." 7 He continues: "but, as the price of this love, we await to pardon you"; Maistre urges him "once the war has deployed its fury, take your heir by the hand and lead him on the battlefield; show him death in a thousand horrible aspects, let him see the piled corpses and scattered members, torn entrails: let him hear the cries of the miserable, dying under the feet of horses, the curses of rage, cries of despair..." After listing all the other horrors of war, he goes on to warn the prince against the wrath of god, who castigates those who "love war, desire it, seek it." "Maistre's point in the letter is clear: war is at once brutal and necessary; it requires obligation, but its obligation is dependent upon a correct understanding of war as a necessity rather than a voluntarily chosen affair. While this text does not carry the heavy metaphysical speculation that marks his later writings, Maistre does invoke the notion of war as "re-establishing equilibrium"; whenever the "balance tilts too much to one end or the other." "Maistre's unmistakable Christian and spiritual tone is here reconciled with staunch patriotism, as the providential aspect of sovereignty is merged with its practical dimension.

The Savoyard's patriotism and military caution is similarly apparent in another important place, namely in the Letters of a Savoyard Royalist to his Compatriots, one of his earlier counterrevolutionary works. This series of four letters, published in the summer of 1793, was addressed to his fellow Savoyard subjects in the French-occupied territory. Those texts already exhibit Maistre's bitter opposition to the Republic, in particular to the assertive militarist ethos which stood at the heart of the Republican levée en masse. In one of the letters, Maistre urges his compatriots not to ally themselves with the French cause; joining in with the Alpine Army would lead them on an aggressive campaign against Italy. Such a campaign, the author warns, would put the Republican army on a collision course, not with the Italian military - a threat which Maistre addresses as trivial — but also with the laws of justice and

\footnotetext{
${ }^{7}$ Joseph de Maistre, Éloge de Victor-Amédée III, duc de Savoie, roi de Sardaigne, de Chipre et de Jérusalem, prince de Piémont (Paris: Hachette Livres BNF, 2018), 63-64.

8 Ibid., 64.

${ }^{9}$ Ibid., 61.
} 
with nature itself. "Nature forbids you from starting a war before the month of May and finishing it after the month of October." 10 "Beyond the redoubtable Alps" awaits for them "a people rich and bellicose, who sees in you the enemies of their altars"; there, "all arms are raised, death is everywhere, safety nowhere; and that land [...] would appear to have risen in order to drink the odious blood." 11

Those texts, which reveal the intricacies of the young Count's political views and loyalties, also offer a particular insight on Maistre's thoughts on war and peace. They show the Sardinian as a loyal patriot, jealous to the independence of his native kingdom, especially in opposition to the violence of the newly founded French republic. His usage of naturalist arguments here is meant to defend this local sovereignty from the onslaught of the new, emerging national form of war. What is at play here is the distinction between national wars, a result of human will and thus human folly, and the natural law which represents a universal equilibrium. Maistre's writings from the latter half of the 1790s, which exhibit a more pious style of argumentation, nonetheless retain the "realist" concerns of his earlier letters.

In his famous pamphlet Considerations on France, written during the crisis years of the French revolutionary regime and published in 1797, Maistre further develops his idea of war as part of his attack on the Enlightenment and its assumptions concerning the nature of human society. Here, war appears not as particular political problem but as a general and universal phenomenon, one which encompasses the entirety of society. Citing "the discoveries of modern psychology and ancient traditions," the Catholic thinker lays out his conception of human violence as innate to human nature. Society, according to Maistre, is founded not on peace and harmony of interests but on conflict and bloodshed. In a chapter entitled "On the Violent Destruction of the Human Species," Maistre offers the thesis regarding the inseparability of war from human life. Writing in an objective, almost clinical style, Maistre describes the role of war as a formative experience in virtually every human society. In this chapter Maistre contends:

if you go back to the birth of nations, if you come down to our own day, if you examine people in all possible conditions from the state of barbarism to the most advanced civilization, you always find war. From this primary cause, and from all the other connected causes, the effusion of blood has never ceased in the world. Sometimes blood flows less abundantly over some larger area, sometimes it flows more abundantly in a more restricted area, but the flow remains nearly constant. ${ }^{12}$

This persistence of war as a human institution leads Maistre to view it as an innate and eternal part of human life, as well as a necessary one. War serves a certain functional end with respect to human life and to human society, namely with regards social and natural equilibrium. As Maistre tells us, "when the human soul has lost its strength through laziness, incredulity, and the gangrenous vices that follow an excess of civilization, it can be retempered only in blood." 13 War is conducive to human society in the long term, as it benefits culture and the arts; while its direct consequence may be calamitous and terrible to particular nations, its indirect effects may be beneficial to humanity as a whole. Maistre compares it to the work of the "skilful gardener [who] directs the pruning less towards lush vegetation than towards

\footnotetext{
${ }^{10}$ Joseph de Maistre, "Lettres d'un royaliste Savoyard", in CEuvres Complètes, 14 volumes, Lyon E. Vitte, 1884-1886, vii, 70. Further references to the Euvres Complètes are cited as OC followed by the volume number.

${ }^{11} \mathrm{Ibid}$.

${ }^{12}$ Joseph de Maistre, "Considerations on France," 62.

13 Ibid., 63.
} 
the fructification of the tree; he wants fruit, not wood or leaves."14 This argument is buttressed by Maistre in his essay $O n$ the State of Nature, an anti-Rousseauian treatise written prior to the Considerations. There, Maistre delivers an attack on the notion of the social contract promoted by modern philosophers, which regards violence as merely a result of a faulty or absent political structure, and can, as such, be vanquished once the political structure was amended. As Maistre contends, the violent and predatory drive cannot be cured or contained, as "man is born evil in a part of his essence." 15

Maistre's increasingly metaphysical notion of war, which emerges around that period, should be regarded in the context of the philosophy of his time. Although it is not likely that Maistre had read Immanuel Kant's Perpetual Peace, he was certainly aware of the views outlined by Enlightenment philosophers which aimed to vanquish war by means of the consistent application of human reason. One of these popular views was offered by the Marquis de Condorcet, who in his influential 1795 treatise dedicated to the progression of science, speculated that the advancement in civilization would eventually lead to the disappearance of national prejudices and by consequence to peace:

The people being more enlightened, and having resumed the right of disposing for themselves of their blood and their treasure, will learn by degrees to regard war as the most dreadful of all calamities, the most terrible of all crimes. The first wars that will be superseded will be those into which the usurpers of sovereignty have hitherto drawn their subjects for the maintenance of rights which we pretend are hereditary. ${ }^{16}$

Maistre's arguments in his writings from the revolutionary period can be seen as directly addressing the views expressed by Condorcet (who is mentioned more than once in the Reflections) and others. In lieu of considering violence and universality as opposite to each other, Maistre regards war as emanating from the very nature of humanity, that is, from universality itself. Maistre's sophistry should thus be seen as ironic on some level: war does not disrupt the general harmony, but rather serves it, and as such cannot be condemned on universal grounds. Inverting the values of Enlightenment philosophy while adopting its "methodology," Maistre sustains a universalist perspective in his writings on war and peace: the universality of warfare pertains both to its nature as an inter- or supra-national activity, but also to its conceptual nature, as it is tied with other domains of human life, including morality, culture, and religion. From this point onward, Maistre would consider war primarily as a general, civilizational phenomenon, involving interrelationship between collective values and culture and the specific methods of war-making. This line of argument would be developed and fleshed out by Maistre under the circumstances of the Napoleonic Wars.

\section{The Napoleonic Wars: Against Warfare as Science}

As devoted as Maistre seems to this metaphysical concept of war, it is somewhat at odds with his more concrete political writings from the era. From 1792 onwards Joseph de Maistre was in exile, wandering around Switzerland and Italy, finally settling in Saint Petersburg in 1802. His writings on war and peace from the period exhibit the unmistakable weight of events: most of his ideas are delivered in the form of letters written to his compatriots. Despite the conquest of Savoyard territories in 1793, Maistre had not abandoned his affinity with his

\footnotetext{
14 Ibid.

15 Joseph de Maistre, "On the State of Nature," in Against Rousseau, ed. Richard Lebrun (Montreal and Kingston: McGill-Queen’s University Press, 1996), 34.

${ }^{16}$ Nicolas de Caritat Condorcet, Outlines of an Historical View of the Progress of the Human Mind (Philadelphia: M. Carey, 1796), 281. Quoted with small changes.
} 
native country and continued to maintain his connections with Savoyard statesmen and notables in his capacity as a diplomat for the court of the King of Piedmont-Sardinia. As is clear from Maistre's correspondence from the period, the defeat of Savoy in 1792 left a strong impression on him. It was, in particular, the swift and nearly bloodless victory of the French Republican Army, which had met almost no resistance in its invasion, which would resonate in Maistre's ideas on the nature of war as determined by public opinion, by morale, and by Clausewitzian Kampfeswillens. In those years, Maistre would develop an idea of war as a cultural project, which is not reducible to mere tactical, logistical, and technical calculations; war and the way it is conducted is a reflection of its society, its mores, habits, and values. As such, this can be traced to what has been defined by Benoit Chantre as the "moment 1806," the date of the Battle of Jena, which triggered significant intellectual interest in the "spiritual" aspects of war on the part of luminaries such as Hegel, Clausewitz, and Hölderlin. ${ }^{17}$

Many of Maistre's remarks on Napoleon echo one of the common themes in Romanesque literature of the time, namely the tendency to see the Emperor at once as an illegitimate usurper and as an agent of modernization. Chateaubriand, for example, in resentment mixed with unmistaken admiration, credits Bonaparte with the invention of the "grande guerre" and recognizes his innovations in the domain of military science. ${ }^{18}$ A more negative view was penned by the members of the Coppet Group, which included prominent writers and statespersons such as Benjamin Constant and Germaine de Staël. Napoleon was regarded by the Coppetians as a new kind of leader, a distinctly modern emperor, motivated by nothing more than personal ambition and adhering to nothing but the "esprit de calcul." In his 1806 pamphlet The Spirit of Conquest and Usurpation, Constant paints a vivid picture of the new type warfare undertaken by Napoleon: the usurpateur leads his armies into war for the sake of his own possessive gain; the modern soldier, writes Constant, is a "gambler, with this difference, that his stake is life itself." 19 This new type of warfare is highly calculated and efficient in its techniques, yet quite brutal in its methods. By modernizing war, Bonaparte also rendered it amoral and excessive. This new spirit of conquest, as an anachronistic and atavistic emergence, could not possibly last and would eventually be relegated into oblivion.

Although Maistre did not share many of the philosophical underpinnings of the romantic thinkers, he was undoubtedly familiar with many of their ideas and writings, having met Germaine de Staël and her circle during his stay in Lausanne. ${ }^{20}$ Maistre's views on Napoleon echo many of their ideas, which had become commonplace in Europe of the early $19^{\text {th }}$ century, including the reference to Bonaparte as embodying a certain principle, or "spirit" of technical and scientific organisation. Maistre's initial assessment of Napoleon is ambivalent: he condemns the Emperor as a usurper, while simultaneously admiring his revolutionary zeal, both in politics and in his willingness to overturn the European order. Maistre hails Bonaparte as the emissary of Providence, a "Meridionel Demon" ["Dæmonium meridianum"], who institutes the type of order previously advocated by Maistre himself. ${ }^{21}$ As a result, Maistre recognizes the utter dominance of Napoleon with respect to sheer force; warning the Russian Emperor of the encroachment of the "usurper," he reminds Alexander that "a king-soldier has never successfully fought against a soldier-king"; and that "gold cannot cut steel."22

\footnotetext{
17 Benoît Chantre, “Le Moment 1806," Commentaire 140 (2012): 1065-1074.

18 François-René de Chateaubriand, Mémoires d'outre-tombe, Vol. 3 (Paris: Garnier, 1910), 246.

${ }^{19}$ Benjamin Constant, "The Spirit of Conquest and Usurpation," in Political Works, translated and edited by Biancamaria Fontana (Cambridge: Cambridge University Press, 1988), 59.

${ }^{20}$ François Descostes, Joseph de Maistre pendant la Révolution: ses débuts diplomatiques, le Marquis de Sales et les émigrés, 1789-1797 (Tours: Alfred Mame et fils, 1895), 385-422.

21 The expression appears in Maistre's letter to Chevalier de Rossi, July 1804, in OC, ix, 91.

22 Joseph de Maistre, Lettres inédites, Revue des Deux Mondes, 5e période, tome 38, 1907, 127.
} 
Maistre, who is aware of the Napoleonic superiority in the field of battle, devises a different strategy to reining in the French empire, which centred on a victory of opinion rather than a military success. His strategy was to pursue the defeat of Napoleon through a war of opinion. In 1806, Maistre wrote to a Sardinian intimate: "Bonaparte cannot be vanquished before being scorned. We must begin by realizing that he grows strong only on account of our weakness. One cannot do worse than to consider him as a Sovereign and a great man." 23

While admiring certain aspects of the Napoleonic genius, Maistre denounced the way in which the Emperor had turned the French state into a war machine by attempting to codify the art of war into a technical theory. This Berenhorstian critique of military science extended to the political consequences of militarism; the French military, Maistre says, has become "a terrible wound within the state." He quips that while every state is to be ruled "con senno e con la mano" (with the chest and with the hand); in the French case, the hand is afflicted with edema and the head with tuberculosis. ${ }^{24}$ Maistre, who already in 1793 castigated the "Batonocracy," that is, the appropriation of political order by military order, regarded the Napoleonic Empire as an implementation of the same principle on a European scale. Maistre, in several places, compares Bonaparte's reign with that of Germany, yet another ancient country which bought into the follies of Enlightenment philosophy, and by consequence devolved into a militaristic and technocratic order. Frederick II, a proclaimed "great man" who in reality was nothing but a "great Prussian," was denounced by Maistre as "one of the worst enemies of humanity," due to the way in which he aspired to rationalize and systematize political power and violence. As Maistre would articulate it later, the Germans have "interposed the uniform between the princes and the eye of the people," and by doing so have tarnished the sacred form of authority; in such a system "the people see in the king nothing more than a grand officer." 25 Maistre even relished the overwhelming victory of the Grande Armée over the Prussian military, whose defeat should serve as a warning for "all of those Sovereigns who would be tempted to build their empires on such mistaken foundations." 26 The "military pedantry," which in his view is a direct outgrowth of Enlightenment philosophy, inevitably leads to the degradation of armies.

Maistre's judgment of the Russian military spirit was initially negative. In his letters from 1806-1807, he identifies Russia as a land contaminated by Enlightenment philosophy, which affected the military among other aspects of life. The Russian fighting man since the $18^{\text {th }}$ century was no longer the free-roaming half-Asiatic barbarian, but a disciplined soldier, a "powdered and oiled" professional drilled beyond the point of exhaustion. Maistre indicts Peter the Great, in particular, for introducing the rationalist system into the Russian military, under the false idea that the nation can be moulded according to his own whims. The Russian soldier, after Peter's reforms, had become the laughingstock of Europe, a mere caricature of the western army man. Reflecting the deep pessimism which characterized his writing from the period, Maistre considerers the state of the Russian military as irredeemably lost, subject to a "thousand symptoms of dissolution." 27

Maistre's assessment of the Russian military underwent a dramatic shift following Napoleon's invasion of Russia in 1812, especially after the Battle of Borodino in September. Borodino, on the outskirts of Moscow, was the decisive turning point in the Napoleonic campaign, described by Maistre in explicitly providential terms. The passage from Maistre's exuberant letter to a Sardinian minister deserves to be brought here in its entirety:

\footnotetext{
23 "Lettre à M, le Comte de Front," Sept. 1806, in OC, x, 196.

24 "Lettre à M le Chevalier de Rossi," Mar. 1810, in OC, xi, 435.

25 "Lettre à M le comte de Front," Sept, 1812, xii, 203.

26 “Lettre à Comte d'Avaray," July 1807, in OC, x, 434-436.

27 "Lettre à Chevalier de Rossi," Aug. 1807, OC, x, 459-460.
} 
This battle, Monsieur le Comte, cannot be sufficiently celebrated; it was won above and beyond all praise, against the enemy of the human race, and for the benefit of all that remains of religion, of independence and of civilization in the universe. Every man and especially every European must be grateful to those who have won. However, if Your Excellency asks me how we got there, I will hesitate to give any answer besides those words: I do not know. ${ }^{28}$

The surprising and miraculous consequences of Borodino led Maistre to revise his initial judgment of Russian military culture. The way in which the Kutuzov's forces engulfed and finally defeated Napoleon is attributed by Maistre to the absolutist and traditional political system and to their adherence to traditional mores; their "unique public spirit, their boundless devotion and unshaken fidelity" which led them to resist Napoleon's army with admirable courage and perseverance. ${ }^{29}$ The Russians, rather than an ancient people spoiled by modern rationalism, begin to embody for Maistre an authentically traditional nation, as he attributes the Russian victory to the "natural spirit of the Russians and their innate common sense," which he opposed to the "crippled military science" of the hopelessly rationalistic French side. ${ }^{30}$

The events that transpired in Borodino led Maistre to return to his old thesis regarding the metaphysical nature of war, which he had developed in the 1790s. Napoleon's defeat, despite the tactical and technical superiority of the French side, and even despite suffering fewer losses than the Russian army, appeared to him as a providential act, a genuine miracle which defies the normal laws of the universe: "the events put to mockery all of human logic. All of our political calculations have been disproven, all of our mistakes have turned in our favor, and that which was seen impossible has happened." ${ }^{31}$ In this unpredictable turn of events, defying normal military logic, Maistre finds an indictment of the spirit of modern military science. In a series of sardonic remarks, he ridicules the strategic pretence of the French: "to vanquish is to advance, while being vanquished is withdrawing. Moscow is taken, end of story. The conservation of the field of battle for a few moments and the number of dead are but twaddle." Maistre continues to mock the French by citing a supposed correspondence between General Daru and Talleyrand, in which the French claim to have won the battle early during its first hours: "where are [the French]? That is the only question. What have they done to get there? God only knows, or at least, those who do know will never tell us." 32

Maistre extends his critique on the rationalist conception of war by suggesting that every war, in fact, is first and foremost a spiritual phenomenon. "Very few battles," he writes, "are lost physically. You shoot, I shoot: who among us has the advantage?"; opinion, which is the "queen of the world, is queen especially in war, and especially since firearms have instituted equality between men." 33 This idea of war as won by the power of opinion is illustrated by Maistre in his retrospective reflections on the razing of Moscow: While for Napoleon, the taking of the Russian capital had clear strategic and political significance, the French side had grossly underestimated the "spiritual" and "moral" consequences of this act. Instead of pulverizing the Russian polity, the destruction of the ancient capital, with its ancient castles

\footnotetext{
28 “Lettre à Comte de Front," Sept. 1812, OC, xii, 220.

29 "Relation pour le Roi Victor-Emmanuel," Nov. 1812, in OC, xii, 285.

30 "Letter of July 1814," in Correspondance diplomatique et militaire (Amsterdam: J.F. Schleijer, 1850), 383.

31 "Lettre à M le Comte de Front," Nov. 1812, in OC, xii, 358.

32 "Lettre à M le Comte de Front," Oct. 1812, in OC, xii, 255-256.

33 "Lettre à M le Comte de Front," Sept. 1812, in OC, xii, 220.
} 
and sacred monuments, has galvanized the Russian "national spirit" against him, and consequently had sealed the fate of his campaign in Eastern Europe. ${ }^{34}$

It was then Russia, the despotic, half-Asiatic, non-Enlightened nation, which took upon itself the necessary sacrifice to become the "saviour of Europe, of France, and by consequence the general equilibrium." 35 Europe was saved, then, not so much by the machinations of statesmen, but rather by the pious dedication of the Russian army and people. If Napoleon represented for Maistre the principle of egoism made flesh, his spirit was far from evacuating from the hearts and minds of Europeans, as he mentioned in a letter from the end of the war. It is the aspiration to imbue European politics with a more spiritual content that marks his later ideas on war and peace, in particular, as found in his magnum opus, The Saint Petersburg Dialogues. In this work, Maistre recapitulates large parts of his previous ideas on war and peace but does so in a way that is more theoretically grounded and in the context of his larger theory of human nature.

\section{Post-Napoleonic Era: From Universal War to European Peace}

As certain commentators have suggested, Maistre's ideas on the balance of power are directly inspired by the experience of Napoleon's wars of conquest. Maistre mentions for example, that "if the Emperor of Russia were fighting against the liberties of Europe, I would side with you against him; but as he fights, on the contrary for his states and even for his capital, I side with him against you [the Swedes allied with Napoleon]." 36 These ideas concerning the balance of power in the classical sense are complemented by Maistre's insistence on the important of opinion, which is similarly inspired by the Napoleonic Wars, and which calls for a different type of regulation, rooted in symbolic forms of ritual and authority.

Dialogues of Saint Petersburg, the most comprehensive work of Maistre's post-Napoleonic period, published posthumously in 1821, grapples with the question of warfare primarily in a theological perspective. In the work, subtitled Conversations on the temporal government of providence, Maistre develops his theological doctrine, whose main principle is the "reversibility of merits," that is, the notion according to which each individual man suffers not according to his own personal sinfulness or virtue, but rather in proportion to the cumulative weight of the sins of all of previous generations; as Maistre puts it, "every man, as a man, is subject to all the misfortunes of humanity." 37 Maistre sets out to demonstrate the workings of this doctrine in a variety of contexts and circumstances; the discussions move between topics such as history, philosophy, religion, and politics. Maistre concentrates, in particular, on extreme and violent phenomena, including plagues, massacres, and executions, which for him exemplify the actions of Providence in the human world. As such, it features some of Maistre's most oftquoted passages, including the long narrative about public execution, or the notorious lines about the "divinity" of war.

Maistre's treatment of war and peace in the Dialogues is rich yet problematic. The discussion on the nature of war is limited to the Seventh Dialogue, inserted almost tangentially with respect to the former discussion. The discussion on war is largely philosophical in nature, invoking a number of historical leaders and battles, but avoiding the mention of any specific recent events, including the revolutionary or Napoleonic Wars. The majority of Maistre's effort in the dialogue is to bolster the notion of war as a metaphysical phenomenon which

\footnotetext{
34 "Lettre au Roi Victor-Emmanuel," Oct. 1812, in OC, xii, 282-284.

35 “Lettre à M le Comte de Vallaise," July 1816, in OC, xiii, 401.

36 "Mémoire sur les intérêts de S.M. le Roi de Sardaigne et de l'Italie en général," Dec. 1813, in OC, xii, 409. Translation is from Camcastle, Moderate Side, 198.

37 Joseph de Maistre, St Petersburg Dialogues or Conversations on the Temporal Government of Providence, translated by Richard Lebrun (Montreal: McGill-Queen's Press, 1993), 16.
} 
eludes the judgment of human beings. Like the other forms of violence evoked throughout the Dialogues, wars are subject to mystical yet visible regularity: wars occur in constant intervals, under specific physical and historical conditions, and cause comparable numbers of casualties.

This mathematical proportionality which characterizes violence and bloodshed marks it in Maistre's eyes as a way for providence to communicate directly with the human race as a divine revelation. War, Maistre writes in a famous paragraph

is divine in itself, since it is a law of the world. War is divine through its consequences of a supernatural nature which are as much general as particular, consequences little known because little studied, but which are nevertheless incontestable [...]. War is divine in the mysterious glory that surrounds it and in the no less inexplicable attraction that draws us to it [...]. War is divine by the manner in which it breaks out. ${ }^{38}$

This passage, which has gained significant notoriety due to the ornate and almost liturgical quality of its rhetoric, should be seen in the context of his earlier proclamations. The "divinity" of war is by no means deduced from its deadly character - Bonaparte surely was no saint in Maistre's eyes. Rather, the passage suggests that the nature and outcome of war is subject to a logic which is not of this world. The emphasis placed by Maistre on the purpose and the reason for the outbreak of war, its causa finalis and its causa efficiens, implies that his intention is not to validate war as a form of violence, but to distinguish it as an autonomous, unique, and even incomprehensible phenomenon. Repeating almost verbatim his language from his 1812 letters, Maistre reminds his reader of the importance, and in fact, the superiority of opinion in matters of warfare, as one of his speakers reiterates:

Opinion is so powerful in war that it can alter the nature of the same event and give it two different names, for no reason other than its own whim. A general throws his men between two enemy armies and he writes to his king, I have split him, he has lost. His opponent writes to his king, He has put himself between two fires, he is lost. Which of the two is mistaken? Whoever is seized by the cold goddess. Assuming that all things, especially size, are at least approximately equal, the only difference between the two positions is a purely moral one. It is imagination that loses battles. ${ }^{39}$

This idea finds its development in Maistre's rejection of any attempt to conceptualize war directly by means of any rational system. In the same dialogue we find the author repudiating the attempt to understand war and peace by means of human reason; not only is perpetual peace rejected as a utopian dream, but also the very attempt to introduce a measure of rational calculation or self-interest in relations between nations. How it is possible, one of Maistre's interlocutors provocatively asks, that no successful attempt has been made to break out of the state of nature which exists in the international sphere? Even if a universal confederation is not possible, surely the union of several nations could institute peace among them and increase their comparative power. The fact that we do not see such attempts succeeding is a testament to the "terrible and mysterious law demanding human blood." 40

In place of rational calculation, Maistre puts forward an idea of the limitation of war which arises from its proportional form. The idea of proportionality in warfare is of course not new; as Maistre knew, it has its origins in the jusnaturalist philosophy of the $16^{\text {th }}$ century, of authors

\footnotetext{
38 Ibid., 218.

39 Ibid., 221.

40 Ibid., 211.
} 
such as Thomas Cajetan, Francisco Suarez, and others. Maistre's adoption of the criterion of proportionality is quite different: it does not pertain or arise from any conscious principle but is rather embedded in the nature of war as a more or less traditional institution. "European war," as Maistre distinguishes it

began in the month of May and ended in the month of December; soldiers refrained from excessive looting and ravaging and fought only other soldiers; whole nations were never at war, and all that was weak was sacred amidst the dreary scenes of this devastating plague $[. .$.$] . It was a magnificent spectacle to$ see all the sovereigns of Europe, restrained by I don't know what imperious moderation, never asking of their peoples, even in the moment of greatest peril, all that it would have been possible to obtain from them. ${ }^{41}$

Traditional war, then, sustained itself not by law or policy but by custom. The other side of this custom, which played a part in its limitation was the special social status accorded to military men: "the soldier is so noble that he ennobles what public opinion regards as most ignoble, since he can act as an executioner without debasing himself, provided however that he kills only his fellow soldiers and that he uses only his weapons to kill them"; the other interlocutor then adds:

wherever, and for whatever reason you like, a soldier is ordered to execute civilian criminals, in a twinkling of an eye and without apparent reason all the glory that surrounds him fades. No doubt he will still be feared, for any man who carries a good and accurate rifle in the course of his day's work merits considerable attention: but the indefinable spell of honour has been irretrievably broken. ${ }^{42}$

Although Maistre's focus in the Saint Petersburg Dialogues differs from his preoccupations during the Napoleonic Wars, there is clear continuity between the two periods (visible even in the expressions which Maistre reuses nearly verbatim): his judgment of the engagement of 1812 as a supernatural event, irreducible to science or technique, is generalized here and transformed into a general idea of the unfathomable nature of war, which eludes any direct rationalization and instead is determined and influenced by opinion, that is, by cultural or civilizational notions such as habit, ritual, and religion.

Above all else, the institutionalization of war is carried out by means of seemingly purposeless rituals. In one of the provocative moments of the seventh dialogue, Maistre invokes the ancient Roman army, in which discipline was presumably maintained by a very specific way: for non-capital punishments, soldiers were not caned by civil magistrates but only by specific officers, who were themselves armed with batons made from vine branches. Maistre's Count describes this as a "consecration" of their form of punishment, since the Romans wanted to refrain from "debasing either the one who strikes or the one who is struck." 43 The author of the Dialogues dedicates an entire paragraph to describing in detail his solution: according to his suggestion, soldiers would be hit only with branches of specific trees grown in specifically designated greenhouses; the laurel replaces the vine, since, as

\footnotetext{
${ }^{41}$ Ibid., 214-215. Note the reiteration of "July to October" from the earlier letters, which is rendered here as "July to December." The last of Napoleon's soldiers had left Russia in December 1812.

${ }^{42}$ Ibid., 247. It should be noted that Maistre distinguishes between honour ["honneur"] and glory ["gloire"]: glory is entirely discarded by him as a motivation for participating in war; not only is it selective, as only the leaders enjoy its glory, and only when they find themselves on the winning side, of course, but also because it fails to explain how war came to bestow this unique glory to begin with (Ibid., 206).

${ }^{43} \mathrm{Ibid}$.
} 
Maistre's Count contends "servile imitations are worthless." 44 This strange and seemingly gratuitous passage illustrates well Maistre's idea of how warfare is ought to be embedded in society, as a non-rational and incomprehensible affair which cannot be curbed by anything but symbolic rituals. The metaphysical nature of war, which operates in the spiritual realm as the principle of the transmission of merit, finds its equivalent in the physical realm in the ritualization of war. It is the symbolic aspect of war, its pomp, its different types of artifice and minutiae, which keeps it at bay and gives it its form; Maistre invokes for example the "dance and spectacles [which] served as interlude for the combatants." 45

It is clear that Maistre's later account of war and peace does not regard war as a national phenomenon, in the same way he did in his earlier works. Rather, Maistre's thought carries a distinctly European tone; his notion of ritualization is more relevant to civilization-wide concepts than purely national ones. In many ways, this idea should be read in light of Maistre's last major work On the Pope, published in 1819. This treatise, one of Maistre's more dialectical and long-winded works, is dedicated to a meticulous historical examination of Church doctrines and of the relations between European princes and the church during the High Middle Ages. Maistre demonstrates his reliance on the method of "experimental politics," and uses this opportunity to offer a sketch for a new European system of power, headed by the Pontiff of Rome. "Without the temporal power of the Popes," he writes, "the political world could not go on; the more this power acts, the fewer wars there are, since it is the only power whose visible interest seeks nothing but peace." 46 Maistre appears here as surprisingly pragmatic and even empiricist: it was through the actual consent of European princes that the Papacy was able to fend off destructive war: "it was a most magnificent spectacle of two nations agreeing to submit their current disagreements, and even their possible disputes, the selfless wisdom of the common Father of the faithful and to put themselves to an ever more imposing arbitration in the place of endless wars." 47

It is safe to assume that Maistre sees the Papal power as the visible emanation of the spiritual power which he designates in the Dialogues. Papal power was the counterweight to the sovereign power of kings, and complements it by way of being a purely spiritual power; "the Pope is no less our superior in the spiritual than the king in the temporal." 48 Needless to say, the Pope's authority is also universal, that is, European, and as such responds to typically European problems; namely it responds to the challenge of "how is it possible to restrain sovereign power without destroying it." 49 Instead of limiting violence at the national level, or through the design of positive statutes to regulate international affairs, he turns to the authority of the only pan-European body whose authority is rooted solely in tradition and in something resembling a consensus. Maistre even turns to a somewhat Montesquieuan language when he described the dynamic between secular powers and the Papal authority in terms of perpetual and benign tension:

Never is violence stopped by moderation. Never are powers balanced by anything other than contrary forces. The Emperors would deliver against the Popes extraordinary excesses which we never mention: these in their turn would place the Emperors within the boundaries of moderation. Those acts would make great and somewhat exaggerated noise, as they are presented to us as in a bundle, but human affairs do not proceed otherwise. Never has a

\footnotetext{
${ }^{44}$ Ibid., 209.

45 Ibid., 215.

46 Joseph de Maistre, Du Pape (Geneva: Droz, 1841), 260.

47 Ibid., 202.

48 Ibid., 41.

${ }^{49}$ Ibid., 144.
} 
political amalgamation been brought about by anything other than the mixing of different elements, which, after having been shocked [choqués] end by mutually interpenetrating and tranquillizing. ${ }^{50}$

What finally emerges from Maistre's writings about war and peace is thus a theory of moderation or "restraint," rooted in a European pluralism of states and curbed by a balance of power. Although Maistre does not offer detailed propositions for the re-institutionalization of a Holy See which would command human affairs (On the Pope in fact ends on a sombre note, denouncing the "fatal errors" of the Greek and Russian Churches), the theoretical relevance for the work to Maistre's ideas of war and peace is clear, as it stresses the importance of the "spiritual" domain for the foundation of a European balance of power. Where Maistre differs from the classical theories of early modern political philosophy is thus in his insistence on the importance of a superior body that would reconcile differences and act as a mediating authority between the warring parties. This body is not a political or legal organization in the normal sense of the word, but an informal institution, whose authority can be seen as a combination between a "traditional" and "charismatic" authority.

\section{Maistre's Legacy in the Study of War and Peace}

The paradoxical nature of Maistre's ideas on war and peace is also reflected in the way in which his ideas have taken root in the history of ideas. It is possible to trace Maistre's legacy in two different intellectual traditions: on the one side, military doctrines and their various strategic applications; on the other hand, the philosophy of war, peace, and international relations in the more theoretical sense. Maistre's influence on military thinkers began in the aftermath of the Napoleonic Wars. Antoine-Henri Jomini, who served as an officer during the Napoleonic Wars in both the Grande Armée and in the Russian army, following his retirement in 1829 became one of the most innovative minds in the study of warfare. Jomini's fascination with the Savoyard author is well known (he even toyed with the idea of writing an epistolary roman in the vein of the Saint Petersburg Dialogues) and is reflected in some aspects of his writings on military affairs. ${ }^{51}$ In his grand work Précis de l'art de la guerre of 1838, Jomini dedicates long segments to the importance of the "esprit militaire," understood as a combination of morale and other, more elusive factors, which contribute to the success of a battle as much as strictly material aspects. In one chapter of the work, Jomini examines the centrality of "vivid imagination" in victory of defeat, and discusses how to sustain the imagination, courage, and other "spiritual" variables. ${ }^{52}$

Maistre's influence would become even more pronounced in the intellectual cadres of the French military on the eve of the Great War. Lucien Cardot, who was an extremely influential figure in the École de guerre during the belle époque, wrote a comprehensive treatise in 1908 entitled On Military Heresies and Apostasies of Our Time. The work, with its "Maistrean" title, quotes the Savoyard author several times. Like Jomini, Cardot encouraged strategic minds to reevaluate questions of morale and motivation in the context of military engagement. For the aging general, the stakes of battle have to do less with tactical or strategic, or even with immediate political considerations, but rather with the readiness to die and be killed. In ornate language, untypical for a Republican military professional, Cardot argued that the central task of a commander is to encourage this sacrificial drive: "we must find the means to lead the

\footnotetext{
${ }^{50}$ Ibid., 211.

${ }^{51}$ See the magisterial biography by Xavier de Courville, Jomini ou le devin de Napoléon (Paris: Plon, 1935).

52 Antoine-Henri Jomini, Le précis de l'art de la guerre, ou nowvean tableau analytique (Paris: Anselin, 1838), $137-147$.
} 
people to the death; otherwise, no war will be possible; this means is familiar to me; it lies in the spirit of sacrifice, and nowhere else." 53

Cardot, who had retired in 1908, would not lead the Republican army in the glorious sacrifice of 1914-1918. This honour would be conferred on one of Cardot's successors, Ferdinand Foch. Foch was one of the most notable French commanders in modern history, serving in the Great War as a high-ranking commander in the Battle of the Marne and on the Somme, and later becoming Commander-in-Chief of the Allied armies. Foch's education, both as a young Jesuit and as a student in the École supérieure de guerre, made him an avid reader of Joseph de Maistre. ${ }^{54}$ Like Cardot, Foch turned to Maistre in order to advocate a "spiritual" idea of war, which for him served to demonstrate the shortcomings of a purely "mathematical" science of war. ${ }^{55}$ As an original military thinker, Foch is remembered for the development of the doctrine of offensive à outrance, which he recognized as a bloody yet effective way of breaking the will of the enemy. ${ }^{56}$

If Maistre's influence in the domain of military thought can generally be seen as escalatory, in the sense of supporting doctrines of aggressive engagement, his influence on general political philosophy has been more complicated. The first political thinker to consider Maistre's ideas on war and peace analytically was Auguste Comte. The $19^{\text {th }}$-century positivist thinker's debt to Maistre is widely recognized and requires no detailed elaboration here. ${ }^{57}$ Like Maistre, Comte endorsed the establishment of a European "spiritual power," which would function as a moral and intellectual authority, modelled explicitly after the Catholic Church. The curious aspect in Comte's thesis belongs to the way in which industrial society, despite its generally pacific character, contains latent tendencies toward competition and tension, as commerce arises from the same psychological motive as "pillage." ${ }_{58}$ Only the spiritual authority, able to influence and modify the mores of human beings, can thus implement peace on a continental or universal scale; the spiritual power thus complements the economic and commercial sphere as a mechanism for the maintenance of peace, much like Maistre's model of the Papacy.

A more paradoxical aspect of Maistre's legacy is his influence on $19^{\text {th }}$-century antimilitarist writers such as Pierre-Joseph Proudhon. Proudhon, one of the founders of anarchist political philosophy, was in many respects an admirer of Maistre's writings on warfare, which he cites consistently throughout his 1869 treatise on war and peace. If Comte intended to rationalize and modernize Maistre's thought on the subject, Proudhon adopts wholeheartedly the more irrationalist and savage elements in his writings on warfare. Proudhon, as an antinationalist and anti-clerical, clearly does not endorse Maistre's propositions regarding the establishment of a European Papacy, and yet adopts much of his critical argumentation. Proudhon cites at length Maistre's declamation on the "divinity" of war, which he defends against the opinions of "so-called rationalists." ${ }^{59}$ Proudhon even shares Maistre's insights regarding the salutary nature of war, and its importance to the invigoration of human society;

\footnotetext{
${ }^{53}$ Lucien Cardot, Hérésies et apostasies militaires de notre temps (Paris/Nancy: Berger-Levrault et Cie, 1908), 89.

54 See Ivan Strenski, Contesting Sacrifice: Religion, Nationalism, and Social Thought in France (Chicago: University of Chicago Press, 2002), 78-79.

${ }^{55}$ Ferdinand Foch, Des Principes de la guerre: conférences faites à l'École supérieure de guerre par le lieutenant-colonel d'artillerie (Paris: Berger-Levrault, 1903), 44.

56 Ibid., 339.

${ }^{57}$ For a recent discussion, see Tonatiuh Useche Sandoval, "Auguste Comte's Reading Of Maistre's $D u$ Pape: Two Theories of Spiritual Authority," in Joseph de Maistre and bis European Readers, ed. Carolina Armenteros \& Richard Lebrun (Leiden: Brill, 2011), 75-92.

58 Auguste Comte, Cours de philosophie positive, Vol. 6 (Paris: Bachelier, 1842), 74-75.

59 Pierre-Joseph Proudhon, La Guerre et la Paix, Vol. 1 (Paris: Lacroix, Verboeckhoven, 1869), 31-32.
} 
a culture without the experience of war would devolve into a purely commercial society, devoid of "the pride of the heroism" and of the "revolutionary faculty." 60 Since war is innate to human society, Proudhon castigates those who wish to curb and restraint war by purely legal means, as war lies beyond the confines of legality, the right of war being a fundamental natural right. ${ }^{61}$

In the $20^{\text {th }}$ century, Maistre's influence has similarly been characterized by heterogeneity. One particularly interesting thinker whose ideas have been influenced by Joseph de Maistre is the French sociologist Gaston Bouthoul. Bouthoul, who founded the "Institut français de polémologie" in 1945, sought to explain war and violence as an indispensable part of human existence. Drawing on Durkheimian and Maussian sociology, Bouthoul's methodology was also inspired heavily by Maistre's works, which he cites throughout his 1951 magnum opus Traité de polémologie. ${ }^{62}$ Bouthoul, a socialist and a pacifist, applied Maistre's ideas regarding the institutionalization of warfare in order to fend off the risk of destructive war, by controlling social variables such as demographic pressure, economic expansion, and so on. This should take place, according to Bouthoul, through the implementation of ritualized practices which would liberate the "spirit of sacrifice", thereby functioning as kind of social safety valve and curbing "polemogenic" forces.

At the other end of the political spectrum of Maistre's readership is the conservative German jurist Carl Schmitt. Schmitt, who refers to Maistre numerous times throughout his writings, valued Maistre's work as an exemplary form of political theology. Although the affinity between the two thinkers is often overstated (there are some important and crucial discrepancies in Schmitt's reception of Maistre, especially with regards to Schmitt's constitutional thought), the German jurist's international thought is much more directly inspired by the Savoyard. ${ }^{63}$ Nomos of the Earth, Schmitt's major work of the post-Second World War period, analyzes the emergence of a European-centric political and legal order during the early modern period. Although Schmitt does not cite Maistre expressly in the Nomos, the work's debt to Maistre, and especially to On the Pope, is undeniable. Schmitt's argument in the work can be seen as complementary to Maistre, as he focuses on the period immediately following the "golden age" of the European Papacy. Schmitt then dedicates a full chapter to explain the doctrinal continuity between Canon law and the European political order, the Respublica Christiana being not only a metaphysical or ecclesial idea, but also a concrete principle of order. ${ }^{64}$ In such a way, the international order after 1492 required the intervention of Papal authority to delineate the Meridional lines where war was sanctioned. The unraveling of political Catholicism in the modern period spelled the doom of the European international order for the German thinker, much like the schismatic tension of the late Middle Ages spelled the doom of the intra-European order for Maistre.

\footnotetext{
60 Ibid., 33.

61 Ibid., 91-93. Maistre's popularity among anti-militarist thinkers of the 19th century is similarly showcased in the works of Lev Tolstoy, the famous pacifist, who paid tribute to Maistre's providential idea of war throughout the masterpiece W ar and Peace. See Vera Miltchyna, "Joseph de Maistre's Works in Russia: A Look at their Reception," in Joseph de Maistre's Life, Thought, and Influence: Selected Studies, edited by Richard Lebrun (Montreal: McGill-Queen's University Press, 2001), 241-270 (more especially 265267).

62 Bouthoul, Gaston. Traité de Polémologie: Sociologie de guerre. Paris: Payot, 1991.

${ }^{63}$ For a close reading of Schmitt's complex affinity with Maistre, see Andrew Garrard Graeme, "Joseph de Maistre and Carl Schmitt," in Joseph de Maistre's Life, Thought, and Influence, 220-238.

${ }^{64}$ Carl Schmitt, The Nomos of the Earth in the International Law of the Jus Publicum Europaeum, translated and annotated by G. L. Ulmen (New York: Telos, 2006), 59-62.
} 


\section{References}

Armenteros, Carolina. The French Idea of History: Joseph de Maistre and His Heirs, 1794-1854. Ithaca: Cornell University Press, 2011.

Armenteros, Carolina and Richard Lebrun, eds. Joseph de Maistre and his European Readers. Leiden: Brill, 2011.

Berlin, Isaiah. The Crooked Timber of Humanity: Chapters in the History of Ideas. London: John Murray, 1990.

Bradley, Owen. A Modern Maistre: The Social and Political Thought of Joseph de Maistre. Lincoln, Neb.: University of Nebraska Press, 1999.

Bouthoul, Gaston. Traité de Polémologie: Sociologie de guerre. Paris: Payot, 1991.

Camcastle, Cara. More Moderate Side of Joseph de Maistre: Views on Political Liberty and Political Economy. Montreal: McGill-Queen's University Press, 2005.

Cardot, Lucien. Hérésies et apostasies militaires de notre temps. Paris: Berger-Levrault et Cie, 1908.

Chantre, Benoît. "Le Moment 1806." Commentaire 140 (2012/4) : 1065-1074.

Chateaubriand, François-René de. Mémoires d'outre-tombe. Vol. 3. Paris: Garnier, 1910.

Comte, Auguste. Cours de philosophie positive. Vol. 6. Paris: Bachelier, 1842.

Condorcet, Nicolas de Caritat. Outlines of an Historical View of the Progress of the Human Mind. Philadelphia: M. Carey, 1796.

Constant, Benjamin. Political Works, translated and edited by Biancamaria Fontana. Cambridge: Cambridge University Press, 1988.

Courville, Xavier de. Jomini ou le devin de Napoléon. Paris: Plon, 1935.

De Maistre, Joseph. Against Rousseau, translated and edited by Richard Lebrun. Montreal:

McGill-Queen's University Press, 1996.

. Correspondance diplomatique et militaire. Amsterdam: J.F. Schleijer, 1850.

Du Pape. Geneva: Droz, 1841.

Éloge de Victor-Amédée III, duc de Savoie, roi de Sardaigne, de Chipre et de Jérusalem, prince de

Piémont. Paris: Hachette Livres BNF, 2018.

The Generative Principle of Political Constitutions: Studies on Sovereignty, Religion and

Enlightenment, translated and edited by Jack Lively. New Brunswick, N.J.: Transaction

Publishers, 2013.

Lettres inédites. Revue des Deux Mondes, 5e période, tome 38, 1907.

CEurres Complètes. 14 volumes. Lyon E. Vitte, 1884-1886.

St Petersburg Dialogues or Conversations on the Temporal Government of Providence, translated by Richard Lebrun. Montreal: McGill-Queen's University Press, 1993.

Descostes, François. Joseph de Maistre pendant la Révolution: ses débuts diplomatiques, le Marquis de Sales et les émigrés, 1789-1797. Tours: Alfred Mame et fils, 1895.

Foch, Ferdinand. Des Principes de la guerre: conférences faites à l'École supérieure de guerre par le lieutenant-colonel d'artillerie Paris: Berger-Levrault, 1903.

Holmes, Stephen. The Anatomy of Antiliberalism Cambridge, Mass.: Harvard University Press, 1993.

Jomini, Antoine-Henri. Le précis de l'art de la guerre, ou nouveau tableau analytique. Paris: Anselin, 1838.

Lebrun, Richard. "Joseph de Maistre's "Philosophic" View of War." Proceedings of the Annual Meeting of the Western Society for French History 7 (1979): 43-52.

ed. Joseph de Maistre's Life, Thought, and Influence: Selected Studies. Montreal: McGill-

Queen's University Press, 2001.

Proudhon, Pierre-Joseph. La Guerre et la Paix Vol. 1. Paris: Lacroix, Verboeckhoven, 1869. 
Schmitt, Carl. The Nomos of the Earth in the International Law of the Jus Publicum Europaeum.

Translated and annotated by G. L. Ulmen. New York: Telos, 2006.

Strenski, Ivan. Contesting Sacrifice: Religion, Nationalism, and Social Thought in France. Chicago:

University of Chicago Press, 2002. 